\title{
Opportunism, Institutions and Moral Costs: the Socio- Cultural Dimension of the Underground Economy in Croatia 1995-1999
}

Štulhofer, Aleksandar; Rimac, Ivan

Source / Izvornik: Occasional Paper Series, 2002, 6, 1 - 14

Journal article, Published version

Rad u časopisu, Objavljena verzija rada (izdavačev PDF)

https://doi.org/10.3326/ops.14

Permanent link / Trajna poveznica: https://urn.nsk.hr/urn:nbn:hr:242:421565

Rights / Prava: Attribution-NonCommercial-NoDerivatives 4.0 International/ImenovanjeNekomercijalno-Bez prerada 4.0 međunarodna

Download date / Datum preuzimanja: 2023-04-26

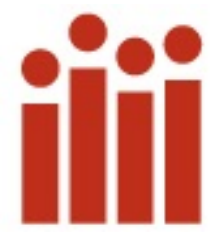

Repository / Repozitorij:

Institute of Public Finance Repository

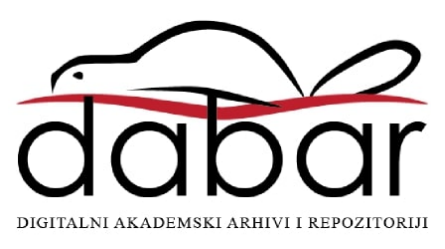




\title{
OPPORTUNISM, INSTITUTIONS AND \\ MORAL COSTS: \\ THE SOCIO-CULTURAL DIMENSION OF THE UNDERGROUND ECONOMY IN CROATIA 1995-1999
}

\author{
Aleksandar Štulhofer \\ Ivan Rimac
}

Occasional Paper No. 14

April 2002 


\title{
OPPORTUNISM, INSTITUTIONS AND MORAL COSTS: THE SOCIO-CULTURAL DIMENSION OF THE UNDERGROUND ECONOMY IN CROATIA 1995-1999
}

\author{
Aleksandar ŠTULHOFER \\ Faculty of Philosophy, Zagreb \\ Ivan RIMAC \\ Ivo Pilar Social Sciences Institute, Zagreb
}

\begin{abstract}
Since the causes and dynamics of the unofficial economy are inseparable from the sociocultural dimension, the authors analyze the dynamics of opportunism and (dis)trust in institutions in Croatia during the last half of the nineties. The analyses carried out are based on work in which the first author provided a theoretical conceptualization of the socio-cultural dimension of the unofficial economy (Štulhofer, 1997). Measurement of the dynamics of opportunism and (dis)trust in institutions was carried out on data collected in the World Values Study - Croatia $1995(\mathrm{~N}=1170)$ and the European Values Study - Croatia $1999(\mathrm{~N}=$ 1003). The results point out that in the observed period the level of opportunism decreased, with respect to both the intensity and to the distribution. Interestingly, there has been no change in the age structure of opportunism (the youngest age cohort is still the most opportunistic). Unlike opportunism, with which it is positively correlated, distrust in institutions has increased, particularly in the youngest age cohort. Considering the theoretical model, in which the level of opportunism reflects the moral costs related to participation in the underground economy, the decrease in the level of opportunism and economic growth in the post-war period suggest a moderate reduction in the underground economy in Croatia during the second half of the nineties.
\end{abstract}

JEL Classification: O17, O52

Key words: underground economy, Croatia, opportunism, trust in institutions, moral costs, socio-cultural factors 


\section{OPPORTUNISM, INSTITUTIONS AND MORAL COSTS: THE SOCIO-CULTURAL DIMENSION OF THE UNDERGROUND ECONOMY IN CROATIA 1995-1999*}

\section{Introduction}

The unofficial, informal, underground or gray economy $(\mathbf{U E})^{1}$ is one of the most interesting of socio-economic phenomena. The reasons are quite familiar: the UE is an omnipresent phenomenon that cannot be precisely measured, its relationship to economic growth and social development still being contradictory (Schneider and Enste, 2000; Portes, 1994; Frey and Schneider, 2000). However, in any consideration of the many paradoxes connected with the UE it is easy to foresee the two central characteristics - its omnipresence and ambiguous relation to growth - on which a systematic analysis of the UE is founded. That is, understanding of the multi-determination of the UE by so-called endogenous (economic) and exogenous (socio-cultural) variables is considerably impoverished if the two dimensions are observed in isolation from each other. Looked at independently, the ubiquitous presence of the UE suggests it is unrelated to the socio-cultural context. On the other hand, taking into consideration the ambiguity of its relation to growth leads to an opposite conclusion. Here it would seem that the UE can be explained only by reference to institutional and socio-cultural properties.

The point of departure for the paper is that the causes and dynamics of the UE cannot be understood in isolation from their social and economic matrix, from the space in which economic and cultural conditions constitute a unified point of origin for individual actions. ${ }^{2}$ This kind of understanding is not new of course (Portes, 1994; Schneider and Enste, 2000; Portes and Sassen-Koob, 1987). The point of drawing attention to it is to recall the importance of an interdisciplinary approach and the need for theoretical and methodological pluralism. Such a procedure is of particular importance in the analysis of the socio-economic events in transitional countries, in which the recent major economic and social changes are still shaping daily reality. The example of the transitional (or post-transitional) societies has clearly delineated the linkage between the economy, politics and culture (Feige and Ott, 1999; Eilat and Zinners, 2000; Stulhofer, 2000).

The paper outlines an analysis of the dynamics of social and cultural factors related to the UE during the second half of the nineties. The first chapter looks at a previous attempt at sociocultural analysis of the UE in Croatia, its results and the methodology applied, which the present paper is closely following. In the second chapter we describe the samples and instruments used, while in the third we present the results of bivariate and multivariate analyses. The final section of the paper offers a short discussion of the findings.

\footnotetext{
* This article is published in Croatia in the journal "Financijska teorija i praksa", 26 (1), 2002., pp. 213228, available at http://ijf.hr/finpraksa/1-02.htm.

1 In this work, the UE or shadow economy is understood to comprise all economic activities, direct or indirect (such as tax evasion) that intentionally avoid inclusion in official statistics - remaining unrecorded. Although this definition is both too narrow and insufficiently precise (Frey and Schneider, 2000) it seems that not a single definition of UE introduced so far has managed to satisfy all of the criteria (Schneider and Enste, 2000: 79).

${ }^{2}$ From this point of view, the differentiation of endogenous and exogenous variables in the context of the UE is a mere convention in economics. This leads to the conclusion that any reduction in the UE will necessarily have to be based on the aggregate effects of socio-cultural, legal and economic changes.
} 


\section{The UE in Croatia}

The first systematic research into the UE in Croatia was started in 1995. According to the results that were published, the UE in the mid-nineties came to "at least 25 percent" of GDP (***, 1997: 11). This figure is comparable with other estimates that place Croatia in the group of countries with an average incidence of UE (Eilat and Zinnes, 2000: 42) ${ }^{3}$ According to these measurements, the greatest growth in the UE in the transition countries occurred in the period between 1990 and 1993, after which stagnation ensued. The leaders of the Croatian research project addressed the negative implications of this kind of dynamics, warning that the UE might become a permanent feature of the national economy (Bićanić and Ott, 1997).

The first author of this paper was involved in the 1995 research. In one of the two project papers he attempted to throw light on the socio-cultural background of the UE in Croatia, positing that social opportunism is a rough proxy for willingness to participate in the UE (Štulhofer, 1997: 136). The most important result, as well as the most worrying, was the finding that it was precisely the youngest and above average educated respondents who were most inclined to opportunistic viewpoints. In the conclusion, this finding was commented on as "the possibility for a 'natural reproduction' of the UE", which could allow for its persistence even in the face of positive advances in the official economy (Štulhofer, 1997: 138).

The obvious limitation of analyzing the UE by measuring opportunism ${ }^{4}$ is a less acute problem if we have longitudinal data at our disposal. Longitudinal comparisons enable the identification of socio-cultural trends that we can then link to economic indicators and econometric measurements of the UE testing the postulated interplay of exogenous and endogenous factors.

The authors of this paper admit with relief that they have not set themselves this task. The objectives of this short study are much more modest and constitute only a part of the preparatory work for the proposed testing. The first of them is to establish changes in the levels of opportunism and distrust in institutions during the 1995-1999 period, and ascertain the dynamics of the moral costs of participating in the UE for specific age cohorts. Thinking about future dynamics of the UE it is highly relevant question whether it is the oldest and economically marginal age cohort or the youngest one the most inclined to opportunism. The other goal is to compare the socio-cultural structure of the UE at two points in time. To meet these goals would be to illuminate the 'exogenous' generator of the UE in Croatia.

\section{Sample and instruments}

The 1997 paper (Štulhofer, 1997) was based on data collected in 1995. In the meantime, a similar research study has been carried out using a largely comparable set of variables (Črpić and Rimac, 2000). The results presented in this and the next chapter are based on the World Values Survey - Croatia $1995(\mathrm{~N}=1,170)$ and European Values Survey - Croatia $1999(\mathrm{~N}=$ 1003). ${ }^{5}$ Both studies were carried out on a national sample using a multi-stage probability method. Surveyed individuals were between 18 and 80 years of age. The main characteristics of both samples are shown in Table 1. It is worth noticing the over-representation of college educated subjects and the under-representation of respondents with only elementary education. This fact is obviously a limiting factor in the interpretation of the results.

\footnotetext{
${ }^{3}$ The authors distinguish three groups of countries, those with small, medium and large UE (less than $20 \%$ of GDP, from 20 to $40 \%$, and more than $40 \%$ respectively).

${ }^{4}$ Obviously, we are measuring only the moral costs of participating in the UE - not the UE itself.

${ }^{5}$ WVS 1995 was carried out by Erasmus gilda, Zagreb, and EVS 1999 by the Catholic Theological Faculty of the University of Zagreb.
} 
Table 1. Socio-demographic characteristics of the sample

\begin{tabular}{|l|c|c|}
\hline & WVS-1995 & EVS-1999 \\
\hline Total number of respondents (N) & $\mathbf{1 1 7 0}$ & $\mathbf{1 0 0 3}$ \\
\hline average age & 46.2 & 39.2 \\
age cohorts (N) & & \\
A (18-29) & $216(18.5 \%)$ & $410(40.9 \%)$ \\
B (30-50) & $506(43.2 \%)$ & $413(41.2 \%)$ \\
C (51-80) & $448(38.3 \%)$ & $180(17.9 \%)$ \\
\hline sex (\%) & 52.7 & \\
F & 47.3 & 57.3 \\
M & & 42.7 \\
\hline education (\%) & 22.8 & \\
primary & 51.3 & 14.3 \\
secondary & 25.9 & 63.5 \\
college/university & & \\
\hline size of birthplace (\%) & 32.5 & 35.4 \\
up to 2 000 residents & 16.1 & 23.2 \\
2 000 - 10 000 & 13.1 & 14.4 \\
10 000 - 50 000 & 20.2 & 11.1 \\
50 000 - 500 000 & 18.1 & 16 \\
Zagreb & \multicolumn{2}{|l}{} \\
\hline
\end{tabular}

Following the outline of analyses presented in the earlier work (Štulhofer, 1997), both samples are divided into three age cohorts (A, B and C; cf. Table 1) in order to establish the effect of generational affiliation on intensity of opportunism and other socio-cultural factors relevant to the UE. The age cohorts could be also viewed as specific macro-networks determined by social roles (for example, the B group is more engaged in professional and family terms than the A group) and the corresponding interests and communication channels.

The following instruments were used in the analyses: ${ }^{6}$

The index of opportunism consists of two variables measuring the attitude towards tax evasion (Can tax evasion be justified?) and corruption (Can bribery be justified?). Each variable used a 10-point scale ranging from 1 (never justified) to 10 (always justified). The index is the average value on both scales, the greater value expressing more pronounced opportunism.

Distrust in institutions was measured by asking respondents how much trust they have in the legal system and parliament (unlike the WVS, the EVS did not ask about trust in the government); answers were scored on a 4-item scale (a great deal, quite a lot, not very much, and none at all).

Preference for egalitarian distribution is one of two indicators of economic traditionalism, which is a characteristic of collectivist economies. The persistence of economic traditionalism, a set of values and habits acquired during the previous economic and political system, can be explained as a consequence of the cultural inertia. Acceptance of egalitarianism was measured by a 10-item scale ranging from $1=$ "we need larger income differences as incentives for individual effort" to $10=$ "incomes should be made more equal". The second indicator of economic traditionalism, the preference for state paternalism was measured by a 10 -item scale ranging from $1=$ "people should take more responsibility to provide for themselves" to $10=$ "the government should take more responsibility to ensure that everyone is provided for".

\footnotetext{
${ }^{6}$ For a theoretical elaboration see Štulhofer (1997).
} 


\section{Results and discussion}

The basic theoretical assumption of the paper is that the dynamics of social opportunism coincide with the dynamics of the UE. The mechanism that binds the two phenomena, the moral costs $(\mathrm{MC})^{7}$, is simple: the expansion of opportunism in everyday interactions leads to a reduction in $\mathrm{MC}$ and a readiness to bypass or breach social norms. The actual breaking of the norms, as participation in the UE presumes, involves certain risks. If they are small enough, i.e. if norm-breaking behavior usually passes unpunished, social opportunism will continue to spread.

As already mentioned, the validity of using opportunism in an analysis of the UE is based on the similarity of their curves, or - if it is to do with a one-off measurement in several countries - in a coincidence of rankings. Figure 1 gives an example of such an analysis carried out on a small sample of transitional countries. Although it does not attain statistical significance (Spearman's $\rho=0.7 ; p>.05$ ), the accordance between the opportunism and the UE ranking is noticeable. $^{8}$

Figure 1. Opportunism and the UE in five transitional countries. ${ }^{9}$

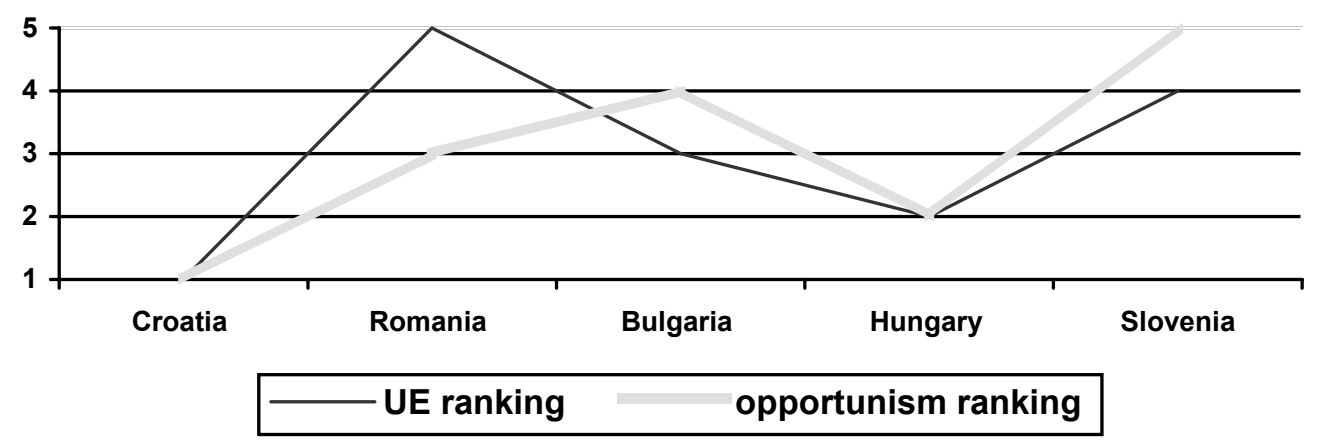

It can be safely assumed that a certain level of opportunism exists within every society. In reality, the economic context and the historically specific cultural development will have a crucial influence on this abstract rate of opportunism. As is well known, in transitional countries both dimensions, economic and cultural, have a markedly unfavorable effect. Transition costs, especially at the beginning of the nineties, led to a dramatic fall in living standards of the majority of the population $(* * *, 1998)$ and led to rapid re-stratification, which (helped by the media accounts of the criminal aspects of privatization) created enormous disappointment and cynicism. In such an anomic situation, the reduction of MC was additionally accelerated by the cultural inheritance marked by distrust in official (communist) institutions and absence of civil society. In other words, the moral climate of the post-communist transition is determined both situationally and historically.

In 1995, the level of opportunism in Croatia was the highest of a group consisting of five transitional countries and five EU countries (Štulhofer, 1997: 130-131). Four years later, the

\footnotetext{
${ }^{7}$ For an empirical assumption indicating different moral prices of procedures associated with tax evasion see Kirchler, Maciejovsky and Schneider (2001).

${ }^{8}$ The higher the rank, the more widespread opportunism and the UE.

${ }^{9}$ UE data are taken from Schneider and Enste (2000: 101-102); for each country, the average value is calculated on the basis of the available measurements. The average size of the UE for all the countries except for Croatia is from the 1990-1993 period, when the level of opportunism was measured by the World Values Survey (Basanez, Inglehart and Moreno, 1996). The UE values for Croatia are from the 1994-1995 period.
} 
intensity of opportunism decreased (Table 2) implying a rise of the moral costs. ${ }^{10}$ More detailed analysis pointed out that the variability of opportunism within the population decreased, too. This suggests an increased agreement about what is socially acceptable, and what is not.

Table 2. The level of opportunism in Croatia 1995-1999

\begin{tabular}{|c|c|c|}
\hline & WVS 1995 & EVS 1999 \\
\hline INDEX OF OPPORTUNISM & \multicolumn{2}{|c|}{ Means (s.d.) } \\
\hline /the larger the number, the more pronounced & $2.9(2.6)$ & $2.2(1.9)$ \\
\hline opportunism $^{11} /$ & \multicolumn{2}{|c|}{$\mathrm{p}<.01$} \\
\hline
\end{tabular}

Figure 2 provides a more detailed insight into the dynamics of opportunism in the given period. The trend towards a reduction in opportunism can be observed both in attitudes toward tax evasion and corruption. But is this a reduction in intensity or in prevalence of opportunism, or a combination of the two? The answer to that question is important when considering the dynamics of the UE. A reduction of intensity at the cost of prevalence could be less desirable than the reverse process. ${ }^{12}$ Our analyses point out simultaneous reduction in both intensity and prevalence of opportunism ${ }^{13}$.

Figure 2. Elements of opportunism: tax evasion and corruption 1995 - 1999

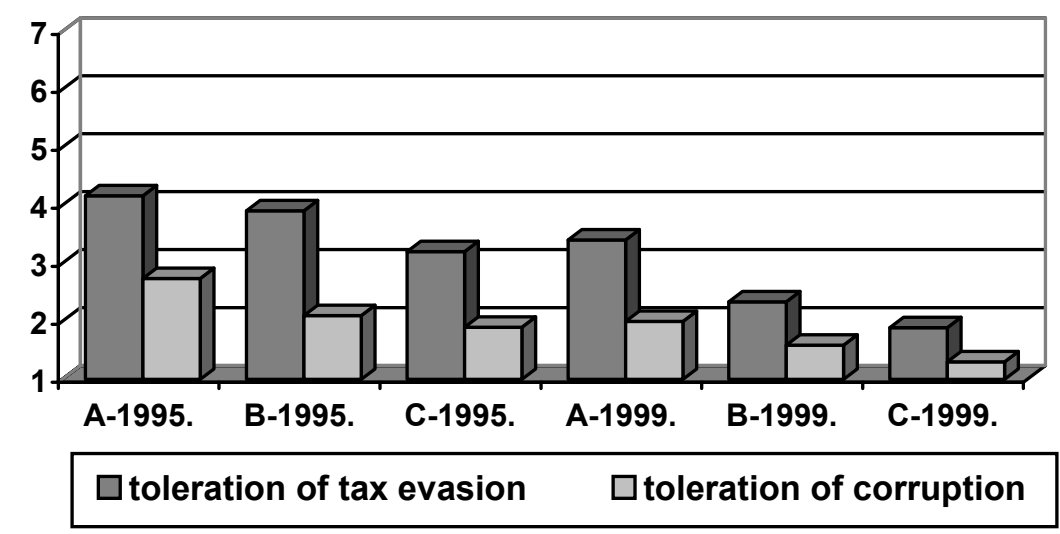

A - youngest age cohort

$\mathrm{B}$ - oldest age cohort

Opposite to expectations, which were based on the length of socialization in the former system, the first author ascertained in his the earlier work that the highest level of opportunism was displayed by the youngest, and not the oldest age group (Štulhofer, 1997).

\footnotetext{
${ }^{10}$ It is reasonable to assume that part of the reduction in the intensity of opportunism can be ascribed to an increased benefit from participating in the official economy, especially with respect to firms with a considerable growth potential.

${ }^{11}$ The scale ranges from 1 to 10 , where 1 denotes an absence of opportunism.

${ }^{12}$ A large number of individuals inclined to tax evasion is a greater problem than a small number of individuals ready to offer bribes in order to reduce their tax burden.

${ }^{13}$ In the 1999 research, twice as many respondents (54\%) as in the 1995 expressed the zero degree of opportunism.
} 
As is shown in Figure 2, there have been no changes in the interim. It is still the youngest age cohort that is most, and the oldest that is least, inclined to opportunism. As in the first measurement, the differences among the age groups are significant in both indicators $(p<.01)$.

The fundamental socio-economic characteristics of respondents inclined to opportunism are given in Table 3. In line with the previous results, opportunism is positively correlated with education and income. Although these are weak links (of only marginal impact in multivariate analysis), which seem to weaken further over time, they do indicate potential resilience of the Croatian UE to changes in the unemployment rate.

Table 3. Correlation between opportunism and selected socio-demographic variables. ${ }^{14}$

\begin{tabular}{|l|c|c|c|}
\hline 1995 & Opportunism & Education & Income \\
1999 & $/$ & $.15^{*}$ & $.18^{*}$ \\
Opportunism & $.15^{*}$ & $/$ & $.11^{*}$ \\
\hline \multirow{2}{*}{ Education } & $.09^{*}$ & $.44^{*}$ \\
& $.18^{*}$ & $.44^{*}$ \\
\hline \multirow{2}{*}{ Income } & $.11^{*}$ & $.30^{*}$ & $/$ \\
\hline \multicolumn{2}{|r}{} \\
\hline
\end{tabular}

The structure of opportunism is also defined by the attitudes toward institutions. According to the earlier study, opportunism was positively linked with distrust in the judicial institutions and the government, and negatively with economic traditionalism, which included a preference toward state paternalism (Štulhofer, 1997: 136). The first finding is hardly surprising: distrust in the institutions of the system - their effectiveness, morality and/or justice - produces opportunism as a rational strategy. The second finding, requires an elaboration. Economic traditionalism, operationalized as the acceptance of egalitarian distribution and collective ownership, and the preference for state paternalism, is a consequence of socialization in a planned economy (Štulhofer, 2000: 106-108). Since it is mostly the respondents in the oldest age cohort who espouse the values of economic traditionalism, their below-average opportunism can be ascribed to both their age - in which withdrawal from economic activity leads to decreasing benefits of opportunism ${ }^{15}$ - and the inherited ideological rejection of the egoism of wealth-making. ${ }^{16}$

Table 4 presents an analysis of the structure of opportunism at two points of time. The dimensions in which the changes occurred are shadowed. As expected, the relation between opportunism and lack of trust in institutions has remained unchanged. Distrust and opportunism, it seems, feed on each other. Interestingly, the correlation is weaker in 1999. The reason for this is different dynamics of the two phenomena. While the level of opportunism has decreased (Table 2), the level of distrust has increased (Figure 4).

\footnotetext{
${ }^{14}$ The coefficients are non-parametric (Spearman's $\rho$ ).

${ }^{15}$ Possibly increasing the corresponding moral costs.

${ }^{16}$ In the collectivist ideology, getting rich is often interpreted as success at the expense of others, achieved by deceit or exploitation.
} 
Table 4. Correlation between opportunism, distrust in institutions, and economic traditionalism

\begin{tabular}{|l|c|c|c|c|}
\hline $\begin{array}{l}1995 . \\
1999 .\end{array}$ & Opportunism & $\begin{array}{c}\text { Distrust in } \\
\text { institutions }\end{array}$ & $\begin{array}{c}\text { Preference for } \\
\text { egalitarian } \\
\text { distribution }\end{array}$ & $\begin{array}{c}\text { Preference for } \\
\text { state paternalism }\end{array}$ \\
\hline Opportunism & $/$ & $.22^{* *}$ & $-.13^{* *}$ & $-.09^{* *}$ \\
\hline $\begin{array}{l}\text { Distrust in } \\
\text { institutions }\end{array}$ & $.16^{* *}$ & .02 & -.04 \\
\hline $\begin{array}{l}\text { Preference for } \\
\text { egalitarian } \\
\text { distribution }\end{array}$ & $/$ & $-.07 *$ & -.02 \\
\hline \multicolumn{2}{|r|}{} & & -.01 & $.31^{* *}$ \\
\hline
\end{tabular}

The relationship between opportunism and economic traditionalism (preference for egalitarian distribution and state paternalism) gives a different picture. The 1995 correlations ceased to be significant. The analyses carried out, including multiple regressions ${ }^{17}$, failed to produce any meaningful interpretation of the change. Having in mind the absence of correlation between the two indicatiors, economic traditionalism - as operationalized in this paper - has to be abandoned as a meaningful theoretical construction. ${ }^{18}$ Regarding the question whether this should be taken as a sign of the disintegration of collectivist values ${ }^{19}$ our data are silent.

Figure 3 shows age differences in the acceptance of egalitarian distribution and preference for state paternalism. For both indicators there is a statistically significant difference between 1995 and 1999 measurements $(\mathrm{p}<.01)$. Particularly interesting is the large decrease in the preference for state paternalism. It is not clear to what extent could this be the result of an increased distrust in the effectiveness, morality and justice of the government (Matić, 2000; Štulhofer, 1999).

Figure 3. Economic traditionalism 1995 - 1999

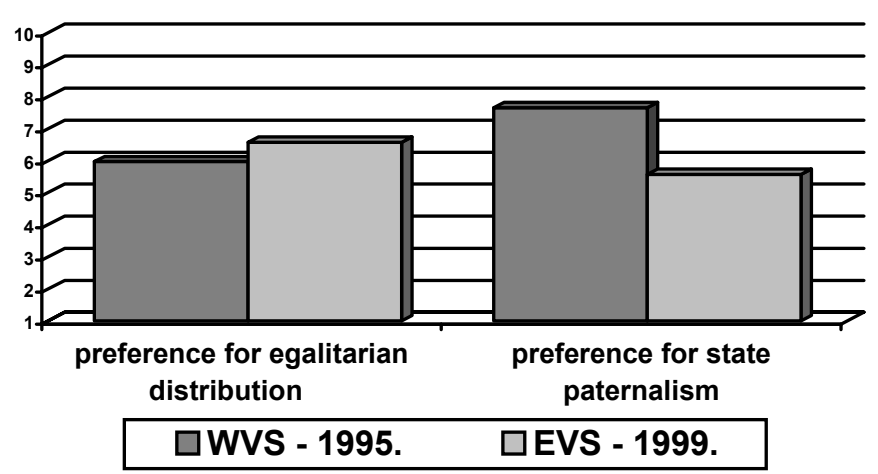

Let us return to the question of (dis)trust in institutions. Figure 4 shows in detail the changes that occurred from the middle of the nineties to the end. The trend in both cases is identical. Lack of confidence in the legal system and the parliament has increased significantly. There

\footnotetext{
${ }^{17}$ Showing that age and distrust in institutions are the most important predictors of opportunism at both points of time.

${ }_{18}$ The differences in the correlations between opportunism and egalitarian distribution, as well as between paternalism and egalitarian distribution (at the two points of time) are statistically significant $(\mathrm{p}<.01)$; the significance was tested using Fisher's z-values (Guilford, 1956).

${ }_{19}$ This is a plausible thesis, since postcommunist transition is now more than a decade old. We should expect certain changes in the perception of economic life due to the operation of market principles.
} 
are undoubtedly a number of reasons for this, but the interpretation should take into consideration the particular moment in which the 1995 research was carried out. WVS data collection was undertaken soon after the last major, and successfully concluded, military operation, which marked the end of the war in Croatia. The timing could have resulted in a momentary eruption of trust in official institutions.

Figure 4. Trust in institutions $1995-1999$ (\%)

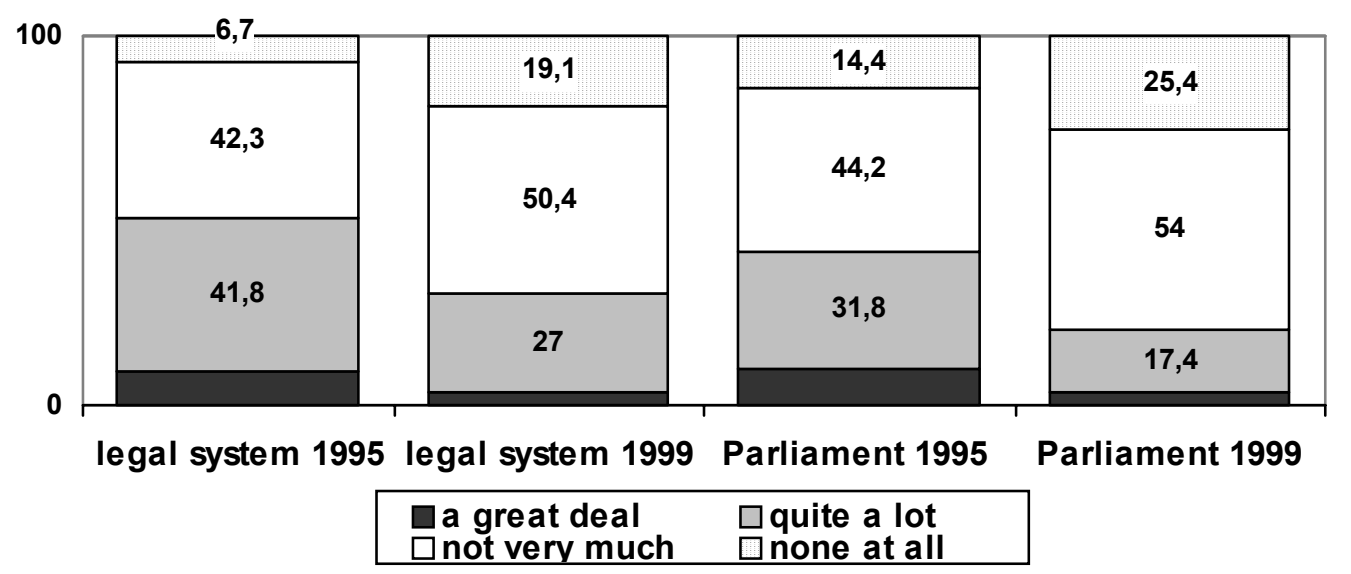

Discussing the demographic structure of distrust, the earlier study established a positive correlation with age (Štulhofer, 1997: 134). According to 1999 data, the difference among the age cohorts had faded away in the case of mistrust in the legal system, but not with respect to the parliament. In both years of measurement, the young express most and the oldest least distrust $(\mathrm{p}<.01)$. There remains, then, the question of how much the distrust of the youngest age group is the reflection of a new postmodern or postmaterialist cultural climate, marked by skepticism, lack of trust and the dissipation of loyalty to formal institutions (Halman, 1995; Abramson and Inglehart, 1995; Fukuyama, 1999; Putnam 2000).

\section{Discussion and conclusion: The UE in Croatia at the end of the nineties}

Reducing the UE is currently high on the list of priorities of many governments. Bearing in mind the considerable rise in the UE in OECD countries in the last forty years (Schneider, 2000) - which has been ascribed to an increase in regulation, the burden of taxes, unemployment, and, finally, to the decline of civic virtue (Schneider and Enste, 2000: 82) this comes as no surprise. In less developed countries, and particularly in the developing world, concern about the $\mathrm{UE}^{20}$ is mostly shared by foreign donors and financiers (Eilat and Zinnes, 2000).

How much, if at all, should Croatia be concerned about the UE? The recent analysis of dynamics of the UE in the transitional countries provides an answer. Although the phenomenon of UE remains complex and often ambiguous, according to Eilat and Zinnes (2000) in the postcommunist transitional setting the UE reflects the failure of institutions. A number of correlations they report on substantiate the claim:

- UE is negatively correlated with economic openness and the volume of investments

- UE is negatively correlated with tax revenue

- UE is positively correlated with corruption

- UE is positively correlated with the degree of economic regulation

\footnotetext{
${ }^{20}$ Which has often the role of an alternative social security network.
} 
- UE is negatively correlated with the development of the banking system and the capital market

- UE is negatively correlated with the rule of law

- UE is negatively correlated with the quality of the political establishment and the development of civil society. ${ }^{21}$

These linkages do not only have major economic consequences. A large or growing UE has a destructive effect on social development in general. Impeding the development of economic institutions and international competitiveness, as well as diminishing social trust, civicness and lawfulness, the UE is a phenomenon that the transitional societies can not afford to ignore. $^{22}$

Croatia does not seem to belong to the group of countries with a small UE (Eilat and Zinnes, 2000: 45; Schneider and Enste, 2000: 101-103). The first systematic attempt at producing an estimate of the size of the Croatian UE was accompanied by a cautious comment pointing out that the effect of a quarter of GDP (which was the estimated size of the UE) on the official economy and economic policy can not, and should not, be ignored (Bićanić, 1997: 24). Thus, ascertainment of the possible changes in the size of the UE is an important task, especially since 1995 was a kind of a watershed, a year in which the war economy disappeared together with its shadiness and adaptive rationality. ${ }^{23}$ If it is established that in the second half of the nineties the size of the UE in Croatia decreased, the task of writing policy guidelines will be very different than in case an increase is diagnosed.

What sort of conclusion about the dynamics of the UE derives from this work? In order to address this question, let us consider briefly the findings presented so far:

1. In the observed period the level of opportunism decreased, both in terms of its intensity and prevalence. ${ }^{24}$

2. The age structure of social opportunism remained unchanged; the youngest age cohort is still the most opportunistic.

3. Unlike opportunism, with which it is positively correlated, distrust in institutions increased. Again, the lack of trust is characteristic for the youngest age cohort.

4. Economic traditionalism ceased to be an important element of the socio-cultural structure of UE.

Opposite trends in the dynamics of opportunism and distrust in institutions make consideration of the dynamics of the UE more difficult. Should we attach greater weight to decreasing opportunism or increasing distrust? Since we have no measures of the relative impact of the two factors on the formation of moral costs, a certain amount of arbitrariness seems unavoidable. With this in mind, we suggest that the decrease in opportunism, and related increase of moral costs, should be considered as more important for the dynamics of UE during the 1995-1999 period. There are two reasons for this: methodological and theoretical. The first relates to a situational refraction of (dis)trust in institutions responsible for a short-term "post-war" increase in trust. ${ }^{25}$ The other argument is based on a theoretical model that postulates a sequential relationship between distrust, opportunism and the UE (Fig.

\footnotetext{
21 "[A] large shadow economy leads to a disintegration of social norms, respect for official institutions, and rule of law" (Eilat and Zinnes, 2000: 4).

${ }^{22}$ Corruption is a good example (Johnson, Kaufmann and Zoido-Lobaton, 1998). Although the UE can also be the result of an over-regulated and thus corrupt system, its growth, directly and indirectly (through the spreading of opportunism), encourages and maintains corruption. This situation is part of the everyday reality in most transitional countries (Krygier, 2001).

${ }^{23}$ In situations of great uncertainty to which the state of war belongs, the moral costs of sidestepping the norms are reduced by the logic of survival. Unpredictability encourages a short-term rationality.

${ }^{24}$ In 1995 some degree of opportunism was displayed by $72 \%$ of respondents. Four years later the figure dropped to $48 \%$.

${ }^{25}$ We are referring to the already mentioned assumption that the 1995 measurement included a temporarily inflated trust in institutions.
} 
5). If lack of trust in institutions precedes an opportunist perception of reality, the dynamics of the latter should be a better predictor of the UE. Is the opposite interpretation equally plausible? What if (inherited) opportunism is a cause, and not the consequence, of lack of trust in institutions? In our opinion such a sequence is possible, but not very probable. The first reason for this is that such a sequence neglects the impact of the powerful initial optimism and public trust in the (new) institutions that arose during the political transformation at the beginning of the nineties, which were perceived as anti-communist and Croatian. Secondly, as one of the authors has demonstrated earlier (Štulhofer, 2000), public perception of the economic processes during the nineties was determined primarily by the reaction to socio-economic reality (situational explanation). The influence of socio-cultural habits (cultural inertia explanation) was marginal, except in the case of the oldest age cohort.

Figure 5. Model of the formation of the moral costs of taking part in the UE.

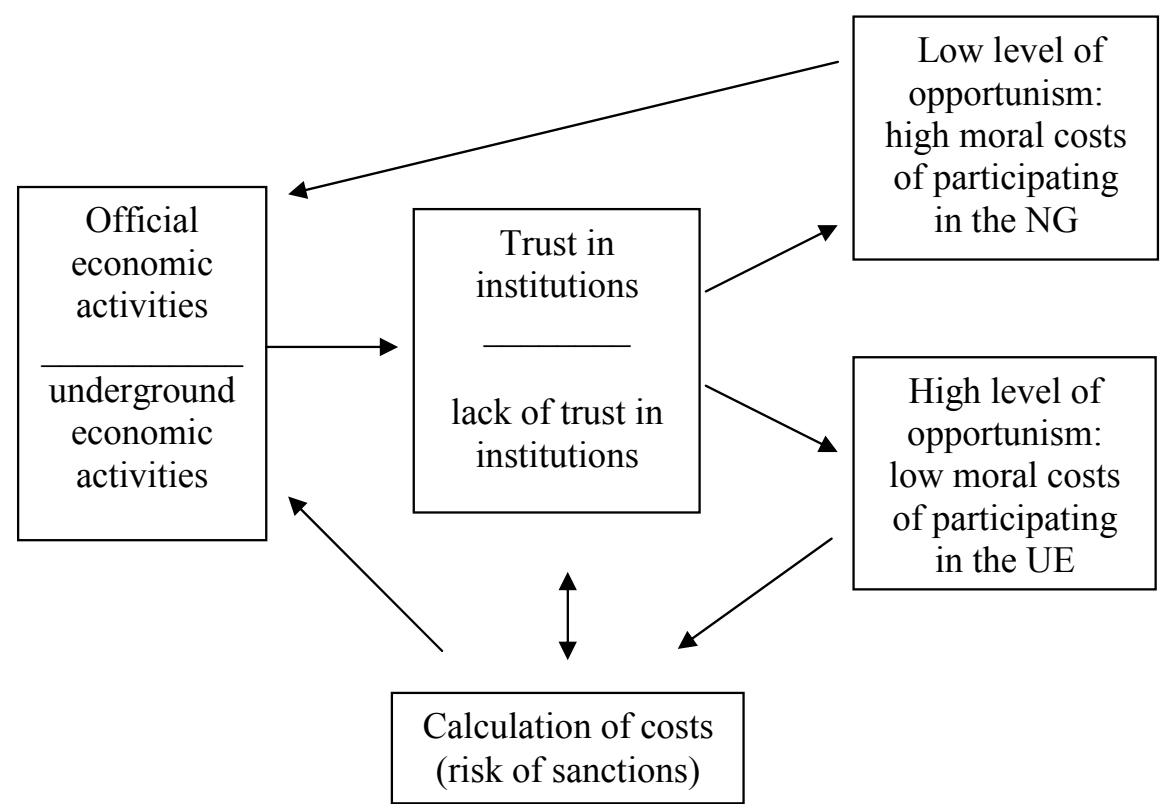

The above speculation is based entirely on the analysis of the socio-cultural dimension. Direct economic and socio-economic effects (growth, improvements in the standard of living, dynamics of unemployment, tax burdens, impact of tax reform, improved efficiency of law enforcement etc.) on the actors' strategic behavior did not enter our discussion. Adding them to our starting point emphasizing the effect of decreased opportunism ${ }^{26}$ - especially the fact that the economic situation in the 1995-1999 period was marked by growth as compared with the preceding period - we predict a mild decrease of the Croatian UE in the second half of the 90 s. ${ }^{27}$

In the words of Schneider (2000: 17), in the next steps it should be worked out in a much more precise way how the shadow economy is also influenced by non-economic influences. We hope that the analysis presented in this paper will read as a suggestion for a fruitful approach in that direction.

\footnotetext{
${ }^{26}$ Decrease in opportunism reflects necessarily either a more positive perception of social and economic transactions, or/and more efficient monitoring and sanctioning of opportunistic acts.

${ }^{27}$ The results of an econometric analysis (Mikulić and Madžarević, 2001) suggest a considerable reduction in the size of the UE (more than 50 percent). Considering the method used, the authors warn that the estimate given "represents the lower limit of the underground economy as a percentage of registered GDP".
} 


\section{LITERATURE:}

***, 1997. Neslužbeno gospodarstvo u RH. Financijska praksa, 21(1-2).

***, 1998. Human Development Under Transition. New York: UN Publications.

ABRAMSON, P. and INGLEHART, R., 1995. Value Change in Global Perspective. Ann Arbor: University of Michigan Press.

BASANEZ, M., INGLEHART, R. and MORENO, A., 1996. Human Values and Beliefs: A CrossCultural Sourcebook. Institute for Social Research working material. Ann Arbor: University of Michigan.

BIĆANIĆ, I, 1997. Mjerenje veličine i promjena neslužbenog gospodarstva. Financijska praksa, 21, 15-28.

BIĆANIĆ, I. and OTT, K., 1997. The Unofficial Economy in Croatia: Causes, Size, and Consequences. Institute of Public Finance Occasional Paper No. 3. Zagreb: Institute of Public Finance.

ČRPIĆ, G. and RIMAC, I., 2000. Pregled postotaka i aritmetičkih sredina: Europsko istraživanje vrednota - EVS 1999. Bogoslovska smotra, 52, 191-232.

EILAT, Y. and ZINNES, C., 2000. The Evolution of the Shadow Economy in Transition Countries: Consequences for Economic Growth and Donor Assistance. CAER II Discussion Paper No. 83. Cambridge, MA: Harvard Institute for International Development. Available from: http://www.hiid.harvard.edu/caer2/htm/content/ pubsauth.htm (09. 09. 2001.)

FEIGE, E. and OTT, K., eds., 1999. Underground Economies in Transition. Aldershot: Ashgate.

FREY, B. and SCHNEIDER, F., 2000. Informal and Underground Economy, in International Encyclopedia of Social and Behavioral Science, Vol. XII, Economics. Amsterdam: Elsevier.

FUKUYAMA, F., 1999. The Great Disruption: Human Nature and the Reconstitution of Social Order. New York: Free Press.

GUILFORD, J., 1956. Fundamental Statistics in Psychology and Education. New York: McGraw-Hill.

HALMAN, L., 1995. Is There a Moral Decline? A Crossnational Inquiry into Morality in Contemporary Society. International Social Science Journal, 145, 419-439.

JOHNSON, S., KAUFMAN, D. and ZOIDO-LOBATON, P., 1998. Regulatory Discretion and the Unofficial Economy. American Economic Review, 88, 387-392.

KIRCHLER, E., MACIEJOVSKY, F. and SCHNEIDER, F., 2001. Everyday Representations of Tax Avoidence, Tax Evasion, and Tax Flight: Do Legal Deifferences Matter? Humbolt-University of Berlin Economics Series Discussion Paper No. 187. Berlin: Humbolt-University.

KRYGIER, M., 2001. The Quality of Civility. In: A. Sajo, ed., To and From Authoritarianism. Amsterdam: Kluwer.

MATIĆ, D., 2000. Demokracija, povjerenje i socijalna pravda. Revija za sociologiju, 31, 183-195.

MIKULIĆ, D. and MADŽAREVIĆ, S., 2001. Procjena neslužbenog gospodarstva sustavom nacionalnih računa. Mimeo.

PORTES, A., 1994. The Underground Economy and Its Paradoxes. In: N. Smelser and Swedberg, R, eds., The Handbook of Economic Sociology. Princeton: Princeton University Press.

PORTES, A. and SASSEN-KOOB, S., 1987. Making It Underground: Comparative Material on the Underground Sector in Western Market Economies. American Journal of Sociology, 93, 30-61.

PUTNAM, R., 2000. Bowling Alone: The Collapse and Revival of American Community. New York: Simon \& Schuster.

SCHNEIDER, F., 2000. The Increase of the Size of the Shadow Economy of 18 OECD Countries: Some Preliminary Explanations. Unpublished paper. Available at:

http://www.economics.uni-linz.ac.at/Members/Schneider/publik.html (12.09.2001.)

SCHNEIDER, F. and ENSTE, D., 2000. Shadow Economies: Size, Causes, and Consequences. Journal of Economic Literature, 38, 77-114.

ŠTULHOFER, A., 1997. Sociokulturni aspekti neslužbenog gospodarstva - između oportunizma i nepovjerenja. Financijska praksa, 21, 125-140.

ŠTULHOFER, A., 1999. Proces privatizacije u Hrvatskoj i hrvatska javnost 1996-1998. U: D. ČENGIĆ i ROGIĆ, I., ed., Privatizacija i javnost. Zagreb: Institut društvenih znanosti I. Pilar.

ŠTULHOFER, A., 2000. Nevidljiva ruka tranzicije. Zagreb: Hrvatsko sociološko društvo. 


\section{INSTITUTE OF PUBLIC FINANCE - OCCASIONAL PAPER SERIES}

No. 1 State Intervention for Growth Promotion in Market Economies. Marina Kesner Škreb, January 1997

No. 2 Estimate of Revenues from the Value Added Tax in the Republic of Croatia. Danijela Kuliš and Žarko Miljenović, October 1997

No. 3 The Unofficial Economy in Croatia: Causes, Size and Consequences. Ivo Bićanić and Katarina Ott, November 1997

No. 4 Price Effects of VAT Introduction in Croatia. Martina Dalić, December 1997

No. 5 Tax Administration Reform in Transition: The Case of Croatia. Katarina Ott, April 1998

No. 6 The Present Sate of the Croatian Public Debt. Zoran Bubaš, December 1998

No. 7 Public Investment in Croatia. Katarina Ott and Anto Bajo, March 1999

No. 8 Welfare Policy and Social Transfers in Croatia. Predrag Bejaković and Alastair McAuley, July 1999

No. 9 Is Unofficial Economy a Source of Corruption? Vedran Šošić and Michael Faulend, November 1999

No.10 Banking Sector Problems: Causes, Resolutions and Consequences. Ljubinko Jankov, March 2000

No.11 Toward a Long-Term Strategy of Economic Development of Croatia: Where to Begin, What to Do, and How to Do It?, Dubravko Mihaljek, June 2001

No.12 The Underground Economy in Croatia. Katarina Ott, March 2002

No.13 An Estimate of the Extent of Tax Evasion in Croatia. Sanja Madžarević Šujster, April 2002

No.14 Opportunism, Institutions and Moral Costs: The Socio-Cultural Dimension of the Underground Economy In Croatia 1995-1999. Aleksandar Štulhofer and Ivan Rimac, April 2002

No.15 Dollarisation and the Underground Economy: Accidental Partners? Vedran Šošić and Michael Faulend, April 2002 